\title{
Energy Security, the European Energy Union and the Mediterranean Countries ${ }^{1}$
}

\author{
By Gregory T. Papanikos*
}

This paper reviews the definition and the measurement of energy security based on an eclectic reading of the most recent literature. Energy security, economic competitiveness and environmental sustainability form an energy strategic trilemma. This trilemma is part of the most recent European strategy to build a European energy Union. This energy union is discussed in relation to the role the non-European Mediterranean countries can play in meeting their own strategic objectives, but at the same time contributing to the European Union's energy strategy. The paper concludes that this energy strategy is possible only if it is embedded in an overall strategy of economic, political, social and environmental development.

Keywords: energy security, European Union, Mediterranean countries, EuroMediterranean relations.

\section{Introduction}

Secure, reliable and affordable supplies of energy have been the strategic objectives of many countries, especially after the oil crisis of 1973. Since then, a number of studies, thinktank reports and government policy documents have been published to define and measure energy security, develop energy strategies, and create energy policies. One thing this literature demonstrates is that no consensus exists on how to define energy security. It appears that energy security is a multidimensional concept, and how it is defined depends upon each country's priorities and special circumstances. Energy security is not a static concept and has changed overtime. Thus, the definition and quantification of energy security is an important issue, because it shapes the energy strategic objective of any country. Measurements assist in analyzing cross-country comparisons and performance trends over time.

However, energy security is not the only objective set by a country's strategic plan. Economic competitiveness and environmental sustainability are also strategic objectives, which may not be compatible with the goal of maximizing energy security. This trilemma echoes many policy papers on energy issues. This is another important issue in the relevant literature because there might be political, economic, social and technological tradeoffs between the three strategic objectives. These often differ from country to country and region to region.

\footnotetext{
* President, ATINER and Honorary Professor of Economics, University of Stirling, UK.

${ }^{1}$ This paper was presented at the roundtable discussion on "Energy Security and Policy in the South European Peninsula and the Mediterranean Basin" organized by the Athens Institute for Education and Research, Monday 30 March 2015, Athens, Greece.
} 
The Mediterranean region and the European Union are two regions which have been at the center of energy security discussions. The European Union (EU) plays a leading role in establishing a regional energy union that takes into consideration security, competitiveness and environmental concerns. During the recent European Council Meeting of 19 March 2015, the EU's commitment to building a European Energy Union was reaffirmed. On the other hand, the nonEuropean Mediterranean countries have developed long-term economic relations, which include energy, with the EU member states. These EuroMediterranean (energy) relations constitute another theme that has received considerable attention in the relative academic and policy related literature.

The purpose of this paper is to discuss these three interrelated issues: the definition and measurement of energy security, the energy security trilemma, and EU-Mediterranean energy relations. The paper is based on the approaches and findings of the most recent studies on energy. The paper is organized in five sections, including this introduction. Section II discusses the issue of defining and measuring energy security. Section III examines the energy trilemma. Section IV summarizes the policy considerations of the European Union's strategy to establish an energy union and how this affects other initiatives to establish networks of energy collaborations with the Mediterranean countries. Section V concludes.

\section{The Definition of Energy Security}

This section is based on Ang et al's (2015) extensive review of energy security. Their study surveyed 104 papers and reports from 2011 to June 2014. They identified 83 different energy security definitions. Evidently, there is no consensus on what energy security is. From all the papers and reports, the authors were able to group the various dimensions of energy security into seven main themes of an energy security definition. These are as follows with the percentage of papers using this theme as part of the energy security definition in parentheses:
A. Energy availability (99\%)
B. Infrastructure $(72 \%)$
C. Energy prices $(71 \%)$
D. Social effects $(37 \%)$
E. Environment (34\%)
F. Governance $(25 \%)$
G. Energy efficiency (22\%)

\section{Energy Availability}

Energy availability is by itself a multidimensional concept and might include the following:

- Diversification of importers (suppliers) 
- Spatial diversity of distribution within the country, which includes distributed generation of renewable resources

- Energy mix diversity, such as renewable and non-renewable resources

- Transport route diversity, such as the existence of several pipelines

Energy availability is almost identical to the definition of energy security. 99\% of the definitions examined by Ang et al (2015) included this dimension of energy security.

\section{Infrastructure}

Investing and maintaining energy infrastructure is critical for the stable and uninterrupted supply of energy. Such infrastructures include oil refineries, power plants, transmission, and distribution of energy to both retailers and industrial users. By its own nature, building energy infrastructure is a longterm and costly investment. Its purpose should be to prevent shortages and blackouts in both the short and long run.

\section{Energy Prices}

Energy prices are very volatile, primarily because of the high fluctuation of oil prices in the international market (Smith 2009). This includes the volatility of the US dollar because crude oil contracts are written in this currency. Even if the dollar price of crude oil remained constant, its euro price would have been very volatile. Today, the euro is traded on par with the US dollar. In 2008, however, one euro was traded at 1.6 US dollar, which would have made the price of crude oil $60 \%$ cheaper even if its dollar price did not change at all.

The average price of energy is important for energy security, but most important is its volatility (standard deviation per time period). High energy price volatility increases the risk of any energy investment. In addition, energy prices affect the entire economy, as has been demonstrated by many studies ${ }^{2}$. Figure 1 shows oil prices in US dollar since 1861. For almost one century, from 1875 to 1975 , the price of oil was relatively stable around 20 US dollars per barrel. After 1975, the oil price became extremely volatile.

\footnotetext{
${ }^{2}$ A synthesis of the relationship between oil prices and macroeconomic performance is given by Barsky \& Kilian (2004). After reviewing selected studies they find mixed empirical evidence of the effect of oil prices on aggregate economy. They also conclude that the Middle East political uncertainty's impact on oil prices and, through this, on the macroeconomy of the advanced countries, is only one of many factors that impact on aggregate economy. Baumeister \& Peersman (2013) find that the demand shocks are more important than supply shocks in affecting oil prices.
} 
Figure 1. Oil Prices in US Constant 2013 Dollars per Barrel, 1861-2013

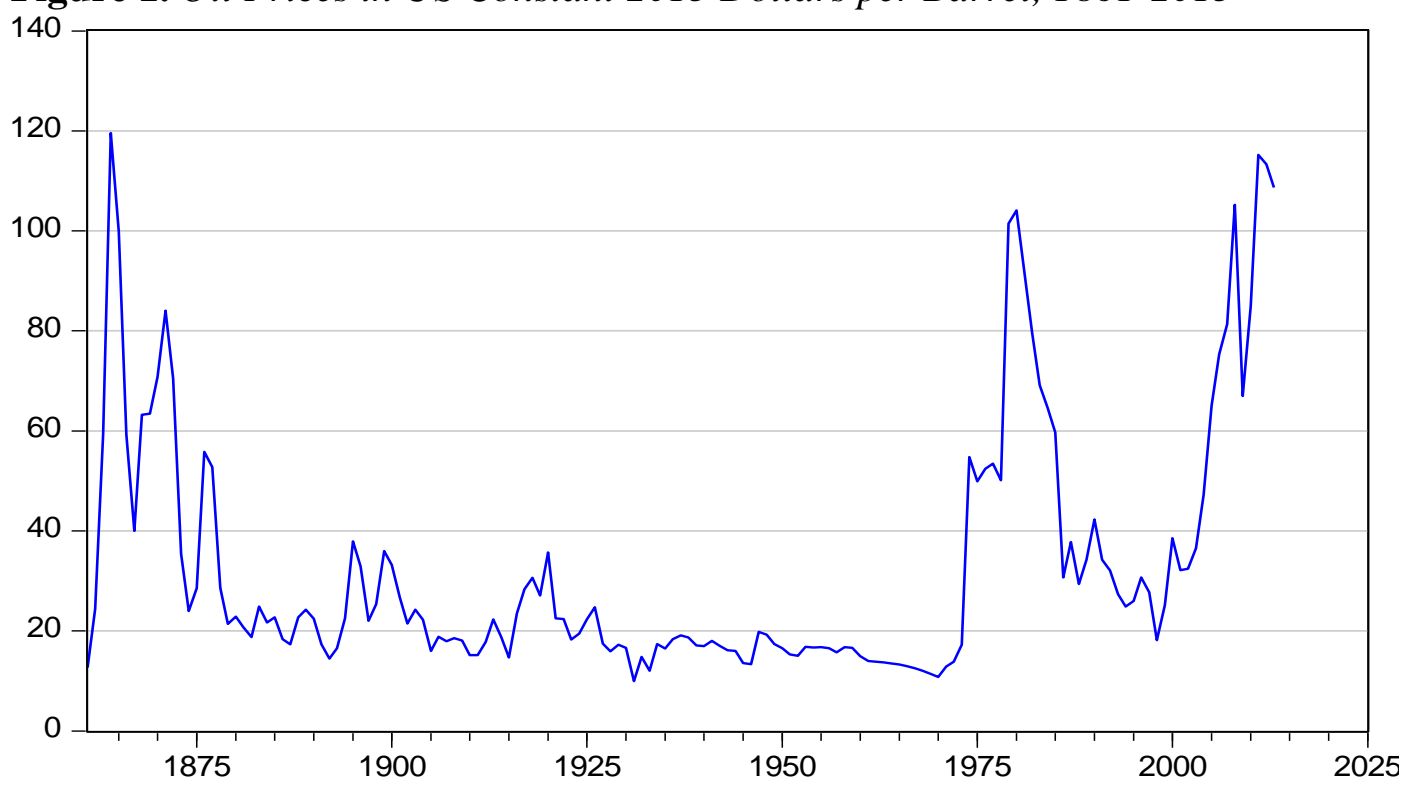

Source: BP-Statistical Review of World Energy, 2014 Workbook

Table 1 shows the average price and its standard deviation, the maximum and minimum price, and its range (maximum-minimum price) per decade. The standard deviation and the range is an indicator of price volatility. Standard deviation and the range of oil prices are low between the 1880s and 1960s. In recent decades, however, the average price of oil has been historically high and very volatile. The average price of oil in the first decade of this century was the highest ever with the third highest volatility.

Table 1. Oil Price Volatility, 1861-2010 (constant 2013 US dollars per barrel)

\begin{tabular}{|c|c|c|c|c|c|}
\hline Decade & Mean & $\begin{array}{c}\text { Standard } \\
\text { Deviation }\end{array}$ & Maximum & Minimum & Range \\
\hline $2001-2010$ & 62.70 & 24.97 & 105.23 & 32.15 & 73.08 \\
\hline $1991-2000$ & 28.48 & 5.68 & 38.55 & 18.17 & 20.38 \\
\hline $1981-1990$ & 53.94 & 22.15 & 92.08 & 29.39 & 62.69 \\
\hline $1971-1980$ & 51.01 & 32.26 & 104.12 & 12.87 & 91.25 \\
\hline $1961-1970$ & 12.81 & 1.09 & 14.01 & 10.79 & 3.22 \\
\hline $1951-1960$ & 16.11 & 0.78 & 16.79 & 14.93 & 1.86 \\
\hline $1941-1950$ & 16.71 & 2.11 & 19.8 & 13.35 & 6.45 \\
\hline $1931-1940$ & 16.08 & 2.99 & 19.14 & 9.94 & 9.2 \\
\hline $1921-1930$ & 19.68 & 3.06 & 24.73 & 15.90 & 8.83 \\
\hline $1911-1920$ & 23.38 & 6.97 & 35.68 & 14.68 & 21 \\
\hline $1901-1910$ & 19.94 & 3.67 & 26.77 & 15.19 & 11.58 \\
\hline $1891-1900$ & 25.82 & 8.61 & 37.93 & 14.46 & 23.47 \\
\hline $1881-1890$ & 21.38 & 2.56 & 24.90 & 17.30 & 7.6 \\
\hline $1871-1880$ & 42.39 & 22.12 & 84.05 & 21.41 & 62.64 \\
\hline $1861-1870$ & 61.27 & 31.92 & 119.56 & 12.65 & 106.91 \\
\hline Total Sample & $\mathbf{3 3 . 0 3}$ & $\mathbf{2 5 . 3 8}$ & $\mathbf{1 1 9 . 5 6}$ & $\mathbf{9 . 9 4}$ & $\mathbf{1 0 9 . 6 2}$ \\
\hline
\end{tabular}




\section{Social Effects}

This issue relates to the social impacts of energy security. It might affect the social stability of the country because of unequal distribution of energy production and consumption. Energy poverty is a key concept in the discussion of energy strategy and policy. This exists when low-income households do not have access to affordable energy services.

\section{Environment}

This issue has received a lot of attention because of climate change concerns. This has effected a shift from fossil fuel use to produce energy to alternative sources, such as solar and wind. Clean energy, which reduces global warming and air pollution, has become a strategic issue and represents one of the three pillars of the energy trilemma discussed in the next section.

\section{Governance}

The energy market is a regulated industry. Government policies secure both the short and long run energy provision. Good governance means that policy-makers are planning to meet the future energy needs of their citizens. Energy governance is multidimensional and requires the collaboration of many government departments (ministries). It requires an optimal design of taxes and subsidies, which not only address the issue of environmental sustainability but also the need to raise government revenues. It also affects governments' foreign policy and diplomacy.

\section{Energy Efficiency}

This requires that production and consumption of goods and services use the least possible energy. Technologies that improve the efficiency of energy use (production becomes less energy intensive) are encouraged.

There are many other ways to group the various dimensions of energy security definitions. For example, Cherp \& Jewell (2014) discuss the 4As as dimensions of energy security (availability, affordability, accessibility and acceptability) and the three questions ("Security for whom?", "Security for which values?" and "Security from what threats?") before they argue in support of "low vulnerability of vital energy systems".

The concept of energy security is not static and evolves over time. Brown et al (2014) examine energy security trends in the last forty years using data from the 22 countries in the OECD. They emphasize four dimensions or criteria of energy security, which are included in the above seven themes, based on 91 studies they reviewed. These are (a) availability (b) affordability (c) efficiency and (d) stewardship. Table 2 gives the definitions of these 
dimensions of energy security and the percentage of the 91 studies in which they appear.

Brown et al (2014) develop indicators for each of the four dimensions of energy security for the 22 countries of $\mathrm{OECD}^{3}$. Table 3 shows the energy security performance for the 22 OECD countries in 2010. Even though data availability makes such comparisons difficult, nevertheless it is a good indicator of energy security. Figure 2 shows the progress of each country on energy security over the 1970-2010 period.

Table 2. Criteria of the Energy Security Definition

\begin{tabular}{|l|c|l|}
\hline Dimension & Frequency & \multicolumn{1}{c|}{ Explanation } \\
\hline Availability & $82 \%$ & $\begin{array}{l}\text { It includes both the different resources of energy and the } \\
\text { different location of supply. }\end{array}$ \\
\hline Affordability & $51 \%$ & Low and stable prices. \\
\hline Efficiency & $34 \%$ & Low cost energy production and low consumption. \\
\hline Stewardship & $26 \%$ & Environmental sustainability. \\
\hline
\end{tabular}

Source: Adjusted from Brown et al (2014, p. 65)

Figure 2. Most to least improved Energy Security, 1970-2010

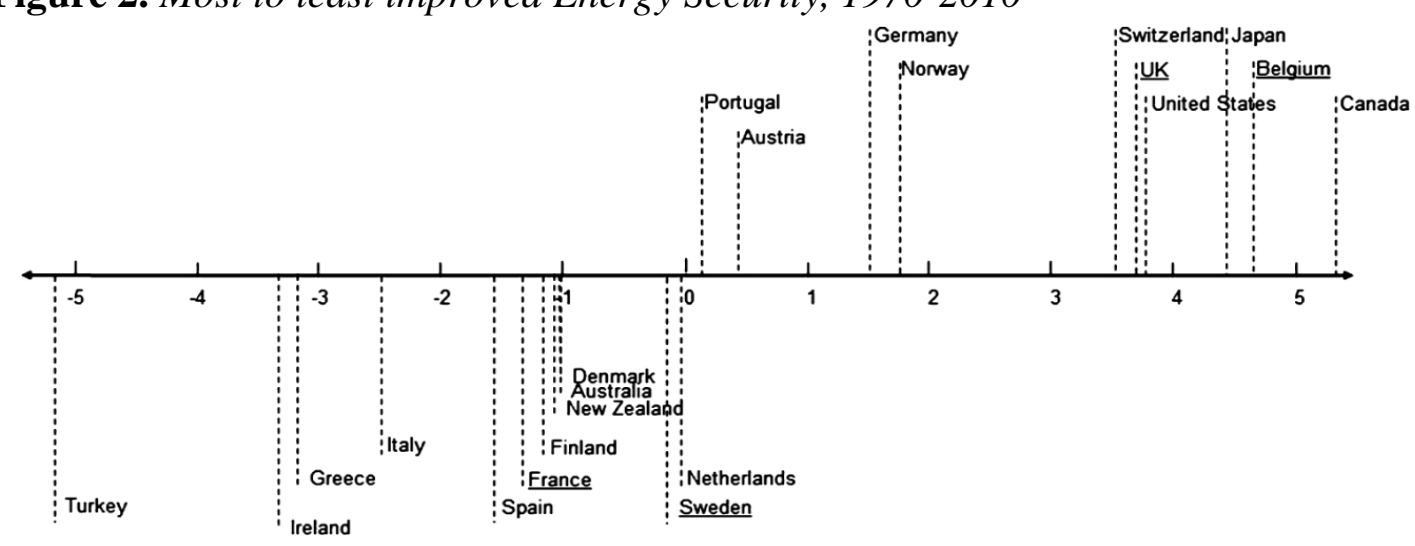

Source: Brown et al (2014, Figure 2, p. 70).

As shown in Figure 2, all the Mediterranean countries of the OECD (Turkey, Greece, Italy, Spain and France) have deteriorating energy security indices from 1970 to 2010. This might call for a Mediterranean regional approach to energy security, as examined in section four below.

Energy security is only one objective of an energy strategy; there are economic and environmental objectives, as well. These make up an energy trilemma, which is examined in the next section.

\footnotetext{
${ }^{3}$ Månsson et al (2014) review the methodologies applied to quantitative evaluations of energy security. Narula \& Reddy (2015) compare three energy security and energy sustainability indices and find country ranking inconsistencies.
} 
Table 3. Energy Security Performance Index for 22 OECD Countries ${ }^{a}$

\begin{tabular}{|c|c|c|c|c|c|c|c|c|c|c|c|}
\hline \multirow[b]{2}{*}{ Country } & \multicolumn{2}{|l|}{ Availability } & \multicolumn{3}{|c|}{ Affordability } & \multicolumn{2}{|c|}{$\begin{array}{l}\text { Energy and economic } \\
\text { efficiency }\end{array}$} & \multicolumn{4}{|c|}{$\begin{array}{l}\text { Environmental } \\
\text { stewardship }\end{array}$} \\
\hline & $\begin{array}{c}\text { Oil import } \\
\text { dependence } \\
(\%)\end{array}$ & $\begin{array}{c}\text { Petroleum } \\
\text { transport } \\
\text { fuels }(\%)^{\mathrm{b}}\end{array}$ & $\begin{array}{c}\text { Natural gas } \\
\text { import } \\
\text { dependence } \\
(\%)\end{array}$ & $\begin{array}{c}\text { Real } \\
\text { electricity } \\
\text { e retail prices } \\
(\mathrm{US} \phi / \mathrm{kWh})\end{array}$ & $\begin{array}{c}\text { Real } \\
\text { gasoline } \\
\text { prices } \\
(\$ / \mathrm{L})^{\mathrm{c}}\end{array}$ & $\begin{array}{l}\text { On-road } \\
\text { fuel } \\
\text { intensity } \\
(\mathrm{gpm})^{\mathrm{d}}\end{array}$ & $\begin{array}{l}\text { Energy per GDP } \\
\text { intensity (tBtu/ } \\
\text { 2005US\$GDP)* }\end{array}$ & $\begin{array}{l}\text { Electricity } \\
\text { use }(\mathrm{kWh} / \\
\text { capita) }\end{array}$ & $\begin{array}{c}\mathrm{SO}_{2} \\
\text { emissions } \\
\text { (million } \\
\text { tons) }\end{array}$ & & $\begin{array}{c}\mathrm{CO}_{2} \\
\text { emissions } \\
\text { (million } \\
\text { tons) }\end{array}$ \\
\hline Australia & $21.2 \%$ & $95.8 \%$ & $0.0 \%$ & 12.5 & 1.27 & 0.038 & 7.7 & 10,386 & 2.4 & 424 & \\
\hline Austria & $82.7 \%$ & $88.8 \%$ & $74.8 \%$ & 20.1 & 1.63 & 0.032 & 5.2 & 7728 & 0.0 & 69 & \\
\hline Belgium & $98.1 \%$ & $94.4 \%$ & $99.3 \%$ & 16.5 & 1.87 & 0.034 & 7.9 & 8141 & 0.1 & 136 & \\
\hline Canada & $0.0 \%$ & $93.2 \%$ & $0.0 \%$ & 7.6 & 1.21 & 0.043 & 10.5 & 15,841 & 1.4 & 547 & \\
\hline Denmark & $0.0 \%$ & $98.6 \%$ & $0.0 \%$ & 39.6 & 2 & 0.033 & 4.6 & 6083 & 0.0 & 46 & \\
\hline Finland & $93.3 \%$ & $95.4 \%$ & $100.0 \%$ & 17.2 & 1.94 & 0.034 & 7.8 & 16,185 & 0.1 & 55 & \\
\hline France & $94.4 \%$ & $91.9 \%$ & $98.4 \%$ & 16.9 & 1.98 & 0.031 & 5.6 & 7300 & 0.3 & 389 & \\
\hline Germany & $92.7 \%$ & $90.3 \%$ & $78.0 \%$ & 26.3 & 1.9 & 0.034 & 5.3 & 6666 & 0.4 & 793 & \\
\hline Greece & $98.0 \%$ & $97.9 \%$ & $100.0 \%$ & 13.0 & 2.05 & 0.034 & 4.7 & 5247 & 0.3 & 93 & \\
\hline Ireland & $98.2 \%$ & $97.5 \%$ & $93.3 \%$ & 26.7 & 1.78 & 0.034 & 4.1 & 5449 & 0.0 & 38 & \\
\hline Italy & $91.0 \%$ & $92.0 \%$ & $90.5 \%$ & 30.5 & 1.87 & 0.030 & 4.9 & 5050 & 0.2 & 417 & \\
\hline Japan & $96.1 \%$ & $97.9 \%$ & $90.4 \%$ & 20.6 & 1.6 & 0.045 & 5.6 & 7801 & 0.8 & 1180 & \\
\hline Netherlands & s $94.9 \%$ & $96.6 \%$ & $0.0 \%$ & 24.3 & 2.13 & 0.033 & 7.0 & 6638 & 0.0 & 255 & \\
\hline $\begin{array}{l}\text { New } \\
\text { Zealand }\end{array}$ & $46.4 \%$ & $99.8 \%$ & $0.0 \%$ & 16.4 & 1.47 & 0.034 & 7.6 & 9585 & 0.1 & 37 & \\
\hline Norway & $0.0 \%$ & $95.3 \%$ & $0.0 \%$ & 16.4 & 2.12 & 0.034 & 8.0 & 25,570 & 0.0 & 45 & \\
\hline Portugal & $97.6 \%$ & $94.2 \%$ & $100.0 \%$ & 22.0 & 1.85 & 0.034 & 5.0 & 4681 & 0.1 & 54 & \\
\hline Spain & $97.4 \%$ & $94.7 \%$ & $99.3 \%$ & 21.8 & 1.56 & 0.032 & 5.3 & 5366 & 0.5 & 312 & \\
\hline Sweden & $97.4 \%$ & $91.8 \%$ & $105.5 \%$ & 12.7 & 1.87 & 0.036 & 6.8 & 15,066 & 0.0 & 59 & \\
\hline Switzerland & $96.2 \%$ & $94.8 \%$ & $100.0 \%$ & 15.4 & 1.66 & 0.034 & 4.4 & 7728 & 0.0 & 42 & \\
\hline Turkey & $85.4 \%$ & $98.1 \%$ & $98.1 \%$ & 16.5 & 2.52 & 0.034 & 5.3 & 2190 & 0.5 & 269 & \\
\hline UK & $13.8 \%$ & $96.3 \%$ & $40.4 \%$ & 23.1 & 1.92 & 0.032 & 4.2 & 5307 & 0.4 & 529 & \\
\hline $\begin{array}{l}\text { United } \\
\text { States }\end{array}$ & $48.6 \%$ & $93.1 \%$ & $10.8 \%$ & 11.6 & 0.76 & 0.050 & 7.5 & 12,564 & 6.8 & 5637 & \\
\hline
\end{tabular}




$\begin{array}{ccccccccccc}\text { Median } & 93 \% & 95.0 \% & 90 \% & 17.1 & 1.87 & 0.034 & 5.5 & 7514 & 0.1 & 195.6 \\ \text { Mean } & 70 \% & 94.9 \% & 63 \% & 19.4 & 1.77 & 0.036 & 6.1 & 5935 & 0.7 & 519.4\end{array}$

${ }^{a}$ The data for oil and natural gas import dependence, electricity retail prices, energy intensity (GDP adjusted for purchase power parity), electricity use, and $\mathrm{CO}_{2}$ emissions is from the U.S. Energy Information Administration's country statistics.

${ }^{\mathrm{b}}$ Data for petroleum transport fuel is from the International Energy Agency.

${ }^{c}$ Retail gasoline price is from the World Bank.

${ }^{\mathrm{d}}$ Data for on-road fuel economy is for 2005 instead of 2010. Specific values for on-road fuel intensity economy for Austria, Canada, Denmark, France, Germany, Italy, Japan, Netherlands, Spain, Sweden, United Kingdom, and United States are from Schipper \& Fulton (2009). Abbreviation: gpm, gallons per mile.

${ }^{\mathrm{e}}$ Data for $\mathrm{SO}_{2}$ emission is from OECD country statistics.

Source: Brown et al (2014, Table 2, p. 68). 


\section{The Energy Trilemma}

Energy security is directly related to two other goals of an energy strategy: economic competitiveness and environmental sustainability. This constitutes an energy trilemma, WEC (2012). Ang et al (2015: 1090) state, "[E]nergy trilemma is defined as balancing the trade-offs between three major energy goals, namely energy security, economic competitiveness, and environmental sustainability". In a schematic way, the relations between the three goals are presented in Figure 3.

For some countries, like Greece, fossil fuels are strategic energy resources because they satisfy the country's need for secure and competitive energy sources. On the other hand, these do not meet the environmental sustainability objective in an optimal way. Conversely, renewable resources are more conducive to the sustainability energy strategy, but often undermine the economic competitiveness strategy of affordable energy.

Figure 3. Energy Security and the Energy Trilemma

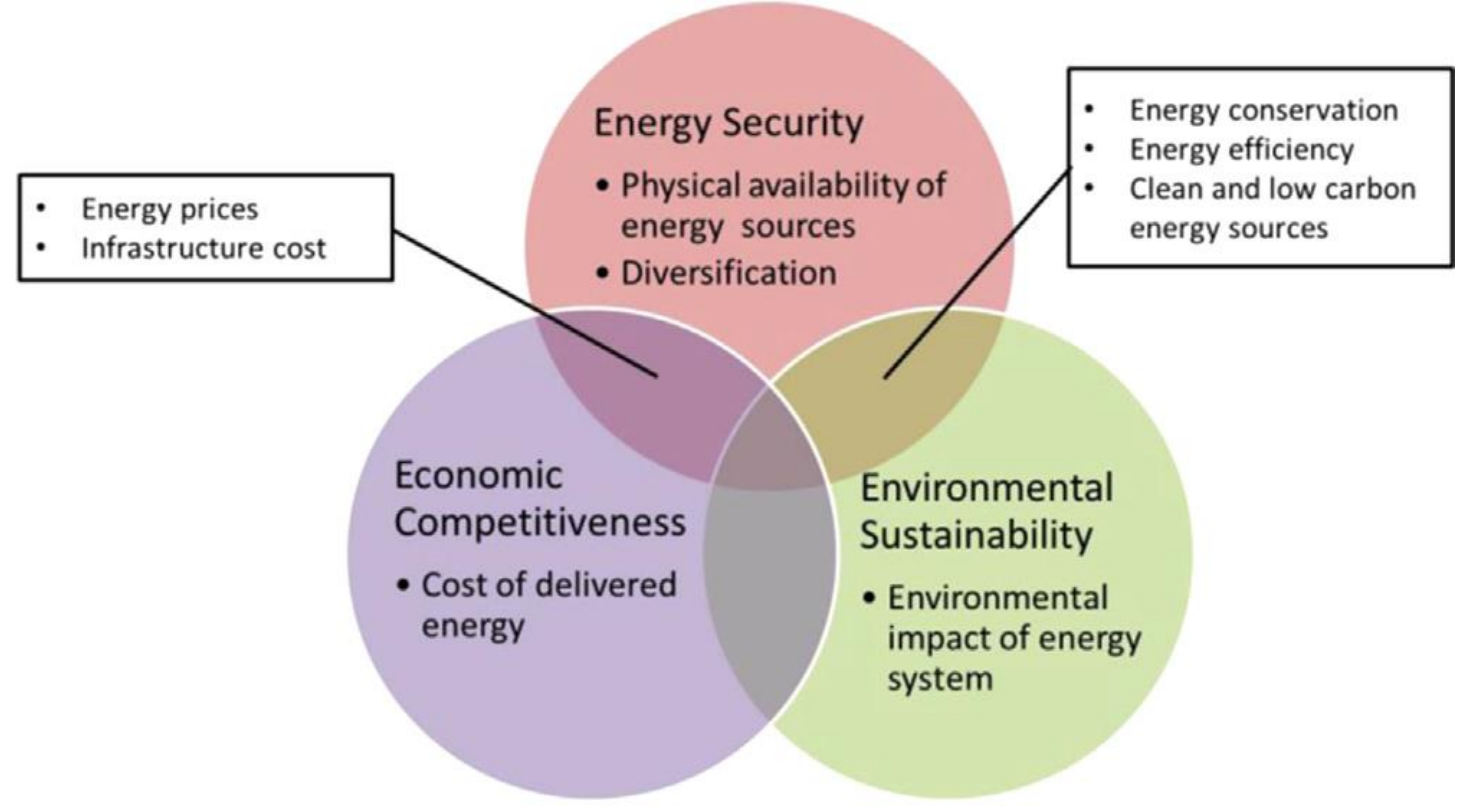

Source: Ang et al (2015, Figure 10, p. 1089)

The European Energy Union and the Mediterranean Countries

There has not yet been a common European Union energy strategy. The European Commission in 2007 attempted to establish an energy policy, which was approved by the European Council (Sencar et al 2014). This common energy policy was based on the three strategic pillars of the energy trilemma: security, competitiveness and sustainability. However, it was not put into effect.

According to recent data reported in the European Commission (2015: 2-3) document: 
"EU imported 53\% of its energy at a cost of around EUR 400 billion, which makes it the largest energy importer in the world. Six Member States depend on a single external supplier for their entire gas imports and therefore remain too vulnerable to supply shocks. It has also been estimated that every additional $1 \%$ increase in energy savings cuts gas imports by 2.6\%. $75 \%$ of our housing stock is energy inefficient. $94 \%$ percent of transport relies on oil products, of which $90 \%$ is imported. Collectively, the EU spent over EUR 120 billion per year - directly or indirectly - on energy subsidies, often not justified. Over EUR 1 trillion need to be invested into the energy sector in EU by 2020 alone. Wholesale electricity prices for European countries are at low levels, though still $30 \%$ higher than in the US. At the same time, post-tax electricity prices for households increased on average by $4.4 \%$ from 2012 to 2013. Wholesale gas prices are still more than twice as high as in the US. The price difference with other economies has an impact on the competitiveness of our industry, in particular our energy-intensive industries. European renewable energy businesses have a combined annual turnover of $€ 129 b n$ and employ over a million people. EU companies have a share of $40 \%$ of all patents for renewable technologies. The challenge is to retain Europe's leading role in global investment in renewable energy".

On 19 March 2015, the European Council again called for the establishment of a European Energy Union. This strategy has five interrelated dimensions:

- Energy security, solidarity and trust

- A fully integrated European energy market

- Energy efficiency contributing to moderation of demand

- Decarbonising the economy

- Research, Innovation and Competitiveness

As part of the energy security strategy, the European Commission calls for the establishment of multiple suppliers. In particular, one of the 15 actions of its strategic plan is to "... work with Member States to develop access to alternative suppliers, including from the Southern Gas Corridor route, the Mediterranean and Algeria, in order to decrease existing dependencies on individual suppliers".

EU's energy relations with the Mediterranean countries have a long history and, at its most recent stage, there is a strategy to create a Euro-Mediterranean Energy Community by establishing a new regional energy model (Abdallah et al 2013). The establishment of such a strategy would replace the bilateral arrangements between the countries of the south Mediterranean with those of the north. According to Abdallah et al (2013) actions to implement such a strategy are:

- Associate North and South in coordinating a common energy strategy

- Harmonize standards (regulatory and technical standards) 
- Promote energy efficiency policies

- Strengthen trans-Mediterranean grid interconnections

- Set up Euro-Mediterranean energy industries and partnerships

- Build partnerships between production, training and research facilities across the Mediterranean region

The EU also promotes energy investments in renewable resources (solar and wind) and energy efficiency as part of its Union of the Mediterranean established in Paris in 2008, a follow up of the Barcelona Process of $1995^{4}$. One of the early goals of the Barcelona Process was to promote collaborations to reach certain targets by 2015 on greenhouse gas emissions ${ }^{5}$. The EU is committed to reducing greenhouse gas emissions $80 \%-95 \%$ by 2050 . Huge investments in renewable resources are needed to meet this target. One such investment is the building of a super grid, which will connect the shores of the Mediterranean basin. Khalfallah (2015) discusses the optimality and the long-term prospects of establishing such an "electricity corridor".

The non-European Mediterranean countries appear to be a source of energy for the EU countries, which have the potential for solving the trade offs of the energy trilemma. The Mediterranean Countries can provide cheaper, cleaner and diverse energy sources for the EU countries (Glachant and Ahner 2013). However, one issue, which is not mentioned as often in the relevant literature, is the future energy need of the non-European Mediterranean countries themselves. Thus, future Euro-Mediterranean energy collaborations should take these concerns into consideration, as well.

Currently, there are many institutional initiatives that aim at promoting the Euro-Mediterranean collaborations as these are described in Glachant and Ahner (2013). The hope is that energy can play the same role that the European Coal and Steel Community played in establishing collaborations between the European countries prior to the establishment of the European Economic Community in 1957.

Energy may compel the non-European Mediterranean countries to collaborate in other areas of social, political and economic interest. Unfortunately, as things stand now, regional collaborations in the non-European Mediterranean countries cannot be promoted for a number of reasons, including lack of infrastructure, appropriate regulatory framework and above all, political will.

The area has great potential; indeed, its solar supply is one of the greatest in the world and requires huge international private and public investments. However, it primarily requires national political support and regional national collaborations. The EU can play a leading role in fostering these regional energy collaborations. This can be achieved by forging a long-term strategy for social, political, economic and sustainable development of the region.

\footnotetext{
${ }^{4}$ An evaluation of these projects is given by Jablonski and Tarhini (2013) and Jablonski et al (2012).

${ }^{5}$ The evaluation of this strategy is given by Cantore (2012).
} 


\section{Conclusions}

Energy security is a multidimensional concept. The European energy security policy has emphasized three dimensions: security, competitiveness and sustainability. These three dimensions form an energy trilemma. Within this context, the non-European Mediterranean countries can become energy strategic partners of the European Union countries. However, this requires more than a simple collaboration on energy. Political, social and economic developments in the Mediterranean Basin should be observed because they have a direct impact on the uninterrupted supply of affordable and sustainable energy, not only for the European Union countries but also for the non-European Mediterranean countries themselves. The two regions must develop together. In doing so, energy can be their common driving force towards achieving first political and social stability and then economic growth and sustainable development.

\section{References}

Abdallah MB, Allal S, Kappauf J, Preure M (2013) Towards a Euro-Mediterranean Energy Community: Moving from Import-Export to a New Regional Energy Model. Retrieved from http://bit.ly/2zW4Chu.

Ang BW, Choong WL, Ng TS (2015) Energy Security: Definitions, Dimensions and Indexes. Renewable and Sustainable Energy Reviews 42: 1077-1093.

Barsky RB, Kilian L (2004) Oil and the Macroeconomy Since the 1970s. Journal of Economic Perspectives 18(4): 115-134.

Baumeister C, Peersman G (2013) Time-Varying Effects of Oil Supply Shocks on the US Economy. American Economic Journal: Macroeconomics 5(4): 1-28.

Brown M, Wang Y, Sovacool BK, D'Agostino AL (2014) Forty years of energy security trends: A comparative assessment of 22 industrialized countries. Energy Research \& Social Science 4: 64-77.

Cantore N (2012) Sustainability of the Energy Sector in the Mediterranean Region. Energy 48(1): 423-430.

Cherp A, Jewell J (2014) The concept of energy security: Beyond the four As. Energy Policy 75: 415-421.

European Commission (2015) A Framework Strategy for a Resilient Energy Union with a Forward-Looking Climate Change Policy. COM (2015) 80 final.

Glachant J-M, Ahner N (2013) In Search of an EU Energy Policy for Mediterranean Renewables Exchange: EU-Wide System vs. 'Corridor by Corridor' Approach. European University Institute, 2013/06. Retrieved from http://fsr.eui.eu/Publica tions/POLICYbrief/Energy/2013/PB201306.aspx.

Jablonski A, Tarhini M (2013) Assessment of selected energy efficiency and renewable energy investments in the Mediterranean Partner Countries. Energy Strategy Reviews 2(1): 71-78.

Jablonski S, Tarhini M, Touati M, Garcia DG, Alario J (2012) The Mediterranean Solar Plan: Project Proposals for Renewable Energy in the Mediterranean Partner Countries Region. Energy Policy 44: 291-300.

Khalfallah H (2015) Connecting Mediterranean Countries through Electricity Corridors: New Institutional Economic and Regulatory Analysis. Utilities Policy 32: 45-54. 
Månsson A, Johansson B, Nilsson LJ (2014) Assessing Energy Security: An Overview of Commonly Used methodologies. Energy 73: 1-14.

Narula K, Reddy BS (2015) Three Blind Men and an Elephant: The Case of Energy Indices to Measure Energy Security and Energy Sustainability. Energy 80: 148158.

Schipper L, Fulton L (2009) Disappointed by Diesel? The Impact of the Shift to Diesels in Europe through 2006. Transportation Research Board Annual Meeting.

Sencar M, Pozeb V, Krope T (2014) Development of EU (European Union) Energy Market Agenda and Security of Supply. Energy 77: 117-124.

Smith JL (2009) World Oil: Market or Mayhem? Journal of Economic Perspectives 23(3): 145-164.

WEC (2012) World Energy Trilemma: Time to Get Real—the Case for Sustainable Energy Policy. London, UK: World Energy Council. 
